\title{
PERJUANGAN PEREMPUAN DALAM SARINAH KARYA SOEKARNO: KAJIAN KRITIK SASTRA FEMINISME MARXIS
}

\author{
Arwan, Mahyuni, \& Nuriadi \\ Universitas Mataram; Jl. Majapahit No.62 Mataram, Telp: 0370633007 \\ Magister Pendidikan Bahasa Indonesia, Fakultas Keguruan dan Ilmu Pendidikan, \\ Mataram \\ e-mail: daewan186@gmail.com
}

\begin{abstract}
Abstrak
Penelitian ini menggunakan metode analisis dekskriptif kualitatif yaitu dengan mengumpulkan kata-kata dan kemudian diinterpretasikan dalam pembahasan. Tujuan dari penelitian ini adalah untuk mengungkap bentuk perjuangan perempuan yang tertuang dalam Sarinah karya Soekarno dengan menggunakan teori kritik sastra feminisme marxis. Berdasarkan hasil penelitian dapat digambarkan bahwa gerakan perlawanan perempuan untuk menentang penindasan terhadap kaumnya sudah terjadi sejak dulu. Gerakan perlawanan tersebut ditandai dengan pemahaman perempuan akan persamaan hak dengan laki-laki. Persamaan hak dari semua aspek kehidupan, hak secara sosial dan politik. Sehingga kewajiban perempuan untuk mendapatkan emansipasi bisa terpenuhi dengan berjuang bersama bahu membahu bersama laki-laki.
\end{abstract}

Kata kunci: Feminisme, Marxis, dan Gerakan Perempuan

\section{PENDAHULUAN}

Perjuangan perempuan dalam mendapatkan persamaan hak dengan lakilaki sudah begitu panjang. Baik itu hak di lingkungan sosial, politik serta ekonomi. Seorang perempuan disini sering mendapatkan simbol sebagai sosok yang memiliki sifat kehalusan. Selain kehalusan perempuan juga sangat identik dengan keterpurukan dan ketertindasan. Perjuangan panjang perempuanperempuan di Indonesia bukan hanya celoteh belaka. Perjuangn tersebut sudah banyak tertuang dalam berbagai rentetan sejarah baik itu sebelum kemerdekaan atau bahkan setelah kemerdakaan bangsa Indonesia dan sampai saat ini. Perjuangan tersebut kemudian tertuang dalam salah satu buku yang berjudul Sarinah karya Soekarno. Buku tersebut menjelaskan tentang fase-fase perjuangan perempuan dan penempatan posisi perempuan yang seharusnya tidak hanya di Indonesia tapi diseluruh dunia. Hal-hal tersebut senada dengan apa yang 
digambarkan oleh Beauvoir (2003:10) bahwa perempuan digambarkan sebagai "alam" yang bercirikan hal-hal yang pasif, statis, permisif, dan domestik. Seolah-olah perempuan "pantas" dan "wajar" menerima semua perlakukan kekerasan terhadap dirinya oleh kaum laki-laki.

Buku sarinah karya Soekarno pertama kali diterbitakan oleh penerbit Oesaha Penerbitan Goentoer Jogjakarta pada tahun 1947. Buku ini bercerita tentang kewajiban perjuangan perempuan Indonesia terbebas dari belenggu dan ikut berjuang terhadap kemerdekaan, dan buku ini diberi judul dengan nama pengasuh Soekarno waktu kecil yakni Mbok Sarinah. Buku ini terdiri dari enam bab atau bagian yaitu: Pertama, "Soal Perempuan", Kedua, "Laki-laki dan Perempuan", Ketiga, "Dari Goa ke Kota", Keempat, "Matriarchat dan Patriarchat", Kelima, "Wanita bergerak", dan Keenam, "Sarinah dalam Perjuangan Republik Indonesia”. Keenam bagian dalam buku tersebut semuanya membahas tentang perjuangan perempuan. Akan tetapi, tidak semua isi karya Sarinah berupa kata, kalimat, dan paragraf akan di jadikan data dalam analisis hanya beberapa bagian yang mengandung unsur-unsur feminisme marxis. Oleh sebab itu, dalam tulisan ini akan di analisis tentang perjuangan perempuan dengan menggunakan kritik sastra feminisme marxis.

Soekarno merupakan sosok founding father bangsa. Soekarno adalah presiden pertama Rebublik Indonesia yang memiliki gagasan serta konsep yang sangat luar biasa. Sebagai sosok yang kuat secara konsep tentu sebagian pemikiran Soekarno dipengaruhi oleh pemikiran Karl Marx atau tokoh-tokoh gerakan kiri lainnya. Soekarno sangat mengagumi gagasan pemikiran Karl Marx. Soekarno sudah menulis beberapa buku yang berkaitan dengan cara pandang kebangasaan dan hidup bernegara. Meskipun karya Soekarno yang berjudul Sarinah tidak semonumenal karya-karyanya yang lain seperti Dibawah Bendera Revolusi atau biografi Penyambung Lidah Rakyat Indonesia yang ditulis oleh Cindy Adams. Akan tetapi, lewat buku Sarinah Soekarno menelaah khusus dan memberikan konsepsi, pemahaman, dan gagasan tentang perempuan.

Penelitian tentang tentang perempuan atau feminisme sudah banyak dilakukan. Akan tetapi penelitian yang menggunakan objek kajian buku Sarinah 
karya soekarno setahu penulis belum pernah dilakukan. Sebagai bahan pembanding untuk menunjang tulisan ini, berikut akan dipaparkan penelitian yang sejenis dengan tulisan ini. Pertama, penelitian yang dilakukan oleh Aminullah (2012) dengan judul Perjuangan Tokoh-tokoh Perempuan dalam Novel Dwilogi Padang Bulan Karya Andrea Hirata dan Relevansinya dengan Pembelajaran Sastra. Penelitian ini menunjukkan bahwa dalam novel tersebut sebagian besar masyarakat bersifat patriarkat yakni dengan menunjukkan dominasi yang sangat kuat terhadap masyarakat. Ketidakadilan yang dialami oleh tokoh perempuan terjadi secara psikis maupun fisik; Kedua, penelitian yang dilakukan oleh Siti Zuhairini (2013) dengan judul; Idealisme Perjuangan Perempuan Sasak Dalam Novel Merpati Kembar di Lombok Karya Nuriadi dan Relevansinya Terhadap Pembelajaran Sastra di SMAN 2 Kediri Lombok Barat. Hasil dari penelitian tersebut menunjukkan masih terdapat fenomena dominasi laki-laki terhadap perempuan, serta diskriminasi yang dialami oleh tokoh perempuan Lale Erna dalam novel tersebut. Diskriminasi tersebut menunjukkan bahwa perempuan masih dijadikan sebagai objek kekeresan dan perempuan hanya ditempatkan sebagai golongan masyarakat kelas kedua.

Berdasarkan pemaparan di atas maka tulisan ini akan menjawab masalah tentang Pertama; bagaimanakah bentuk gerakan perlawanan perempuan untuk menentang penindasan terhadap kaumnya dari perspektif kajian feminisme marxis, dan Kedua; bagaimanakah arti penting peranan perempuan dalam memperjuangkan emansipasi dan atau persamaan hak perempuan Indonesia.

\section{KAJIAN PUSTAKA}

Memahami suatu alur perjuangan tentang perempuan, baik itu perjuangan kelas dan atau perjuangan dalam ranah sosial, politik, serta ekonomi merupakan suatu bagian yang secara ilmiah dituangkan dalam benyak teori. Teori yang membahas tentang perjuangan perempuan sudah sangat beragam dan salah satunya adalah feminisme. Teori feminis merupakan label umum yang diberikan untuk perspektif atau kelompok teori yang berusaha mengeksplorasi makna dalam konsep-konsep gender (Priyatni , 2010:50). Pengertian lain yang juga dipaparkan 
oleh Ratna (2011:184), feminis adalah gerakan kaum wanita untuk menolak segala sesuatu yang dimarginalisasikan, disubordinasikan, dan direndahkan oleh kebudayaan dominan, baik dalam bidang politik dan ekonomi maupun kehidupan sosial pada umumnya.

Feminisme adalah suatu ideologi pembebasan yang berkeyakinan bahwa perempuan selalu mengalami penindasan, ketidakadilan, hegemoni, dan diskriminasi oleh kaum patriarki, sehingga perempuan menggugat untuk mendekonstruksi struktur patriarki Humm (dalam Darma 2009:143-144). Sama halnya apa yang dijelaskan oleh Ratna (2010:409-413) yang mengatakan bahwa gerakan feminis, khususnya yang berkaitan dengan hakikat perempuan, pada umumnya dikaitkan dengan emansipasi kaum perempuan, yaitu gerakan perempuan untuk menuntut persamaan hak dengan kaum laki-laki, baik dalam bidang sosial, politik, ekonomi, maupun bidang kebudayaan pada umumnya.

Istilah feminisme muncul pada abad ke-17 dan pada saat itulah feminisme itu digunakan (Darma, 2009:139). Sebagai gerakan modern, feminisme lahir awal abad ke-20, yang dipelopori oleh Virginia Woolf dalam bukunya yang berjudul $A$ Room of One's Own (1929). Perkembangannya yang sangat pesat yaitu sebagai salah satu aspek teori kebudayaan kontemporer, sangat kontekstual, berkaitan dengan aspek-aspek sosial, politik, dan ekonomi (Rama, 2011:183).

Konsep feminisme marxis lahir dari pemikiran seorang filsuf asal Jerman yang sangat terkemuka yang bernama Karl Henrich Marx. Bagi feminisme marxis, penindasan kaum perempuan adalah bagian dari penindasan kelas dalam hubungan produksi. Senada dengan pandangan Karl Marx (dalam Soekanto, 2009:38) yang mengatakan bahwa selama masyarakat terbagi atas kelas-kelas, maka pada kelas yang berkuasalah akan terhimpun segala kekuasaan dan kekayaan. Selama masih ada kelas yang berkuasa, eksploitasi terhadap kelas yang lebih lemah akan tetap terjadi. Dalam hubungannya dengan keterpurukan kaum perempuan, sahabat Karl Marx, yaitu Engels menjelaskan bahwa keterpurukan itu bukan disebabkan oleh perubahan teknologi melainkan karena perubahan organisasi dalam kekayaan. Oleh karena kekayaan berkaitan dengan produksi dan laki-lakilah yang mengontrol produksi itu, maka laki-laki mendominasi hubungan 
sosial dan politik, dan perempuan direduksi menjadi bagian dari property belaka. Penindasan terhadap kaum perempuan merupakan kelanjutan dari sistem eksploitasi yang bersifat struktural, sehingga penyelesaian masalahnya pun harus bersifat struktural, yaitu dengan melakukan perubahan struktur kelas dan pemutusan hubungan dengan sistem kapitalisme internasional (Fakih, 2010: 8889).

Dalam sastra, feminis berhubungan dengan konsep kritik sastra feminis, yaitu studi sastra yang mengarahkan fokus analisis pada wanita (Sugihastuti, 2009:21). Walaupun fokus analisisnya pada perempuan, namun seperti yang dikatakan oleh Yoder (dalam Sugihastuti dan Suharto, 2010:5) kritik sastra feminis itu bukan berarti pengkritik perempuan, kritik tentang perempuan, atau kritik tentang pengarang perempuan. Arti sederhana kritik sastra feminis adalah pengkritik memandang sastra dengan kesadaran khusus, kesadaran bahwa ada jenis kelamin yang banyak berhubungan dengan budaya, sastra, dan kehidupan kita. Jenis kelamin inilah yang membuat perbedaan di antara semuanya yang juga membuat perbedaan pada diri pengarang, pembaca, perwatakan, dan pada faktor luar yang memengaruhi situasi karang mengarang. Darma (2009:161) mengutip pendapat Stimpson yang mengatakan bahwa karya sastra sebagai sesuatu yang berguna bagi pengarahan kebebasan perempuan. Bahkan, menurut Stimpson, asal mula kritik feminis berakar pada protes-protes perempuan melawan diskriminasi yang mereka derita dalam masalah pendidikan dan sastra.

\section{METODE PENELITIAN}

Metode yang digunakan dalam penelitian ini adalah metode deskriptif kualitatif. Analisis deskriptif adalah data yang dikumpulkan berupa kata-kata, gambar dan bukan angka-angka (Moleong, 2002: 6). Objek penelitian yang dianalisis adalah perjuangan perempuan dalam Sarinah karya Soekarno: kajian kritik sastra feminisme marxis. Pada penelitian ini data dikumpulkan menggunakan cara studi kepustakaan, serta menganalisis dengan metode analisis diskriptif kualitatif dengan beberapa langkah sebagai berikut; Pertama, membaca buku sarinah secara cermat, Kedua, menandai bagian dari buku sarinah yang 
berhubungan dengan konsep feminisme marxis, Ketiga, data dianalisis dengan menggunakan teori feminisme marxis, Keempat, serta melakukan interpretasi data. Kemudian, hasil analisis dideskripsikan dan interpretasi.

\section{HASIL DAN PEMBAHASAN}

Berdasarkan pemaparan permasalah dalam penelitian ini diperoleh datadata sebagai bahan untuk melakukan analisis. Data yang didapatkan diolah berdasarkan fakta serta teori penunjang dalam penelitian ini. Selanjutnya analisis data-data tersebut akan dipaparkan dalam pembahasan sebagai berikut.

\section{Gerakan Perlawanan Perempuan untuk Menentang Penindasan}

Gerakan perlawanan perempuan untuk menentang penindasan dalam penelitian ini ditemukan sebagai upaya kaum perempuan terlepas dari setiap permasalahan yang membelenggu mereka. Menurut Sofia (2009, 60-63), hal yang melatarbelakangi sikap perempuan untuk menolak bahkan memberontak kekuasaan laki-laki disebabkan oleh pendidikan, pemahaman hukum, dan orangorang disekitar. Gerakan perlawan tersebut berawal dari sebuah persoalan pokok para perempuan diseluruh Dunia. Perempuan Indonesia juga memiliki sebuah persoalan yang memiliki kesamaan dengan perempuan diseluruh Dunia. Persoalan-persolan tersebut dapat dipaparkan sebagai berikut.

"satu soal telah berputar di kepala saya. Bukankah perempuan yang mengintai tadi itu istrinya tuan rumah? Mana bisa, tuan rumah toh mengatakan, bahwa istrinya sedang merawat orang sakit? Tetapi... mengapa ia tadi kelihatan malu-malu, telinganya kemerah-merahan, tatkala ditannya di mana istrinya?" (Soekarno, 2014:4)

Kutipan tersebut menunjukan bahwa permasalahan mendasar perempuan Indonesia saat itu adalah tentang penguasaan laki-laki dalam rumah tangga. Ketika ada tamu yang datang ke rumah maka perempuan tidak diperbolehkan oleh suami untuk menjamu tamu tersebut. Perempuan hanya akan disimpan di balik kain tabir pintu. Sehingga yang nampak hanya kaki dan ujung sarung yang kellihatan di bawah tabir tersebut oleh tamu yang datang. Hal ini, menunjukkan 
bahwa perempuan hanya akan dipasung di dalam rumah tidak diberi sebuah kebebasan bahkan untuk menjamu tamu di dalam rumah.

Laki-laki sebagai suami dengan sebuah pemikiran untuk menjaga istri mereka dari godaan dan dunia luar. Perempuan layaknya diprivatisasi oleh perseorangan. Hal ini juga dikuatkan dengan pengakuan suami dalam kutipan di atas ketika ditanyakan oleh tamu, dia mengatakan bahwa istrinya sedang menjenguk keluarga yang sakit. Sementara jelas-jelas bahwa istrinya sedang berada di rumah. Suami bahkan berani berbohong mengatakan kepada tamu bahwa istri sedang tidak ada di rumah. Jelaslah bahwa saat itu kekuasan mutlak perempuan sebagai istri dikuasai penuh oleh laki-laki.

Hakikatnya menurut para laki-laki bahwa perempuan itu harus dimuliakan, dicintai, dan dihargai. Tetapi, terkadang mereka lupa bahwa bentuk kemulian serta kecintaan itu menjadi hal yang sangat keliru dan merugikan perempuan. Perempuan diumpamakan sebagai sebuah mutiara yang sangat berharga, dengan itu bahwa perempuan harus disimpan rapi dalam sebuah kotak agar tidak dilihat oleh orang lain. Akan tetapi memperlakukan perempuan atas nama kemuliaan justrun membuat laki-laki menguasasi atau mendominasi perempuan. Stanton (dalam Madsen, 2000:38-40) mengemukakan bahwa hubungan antara lelaki dan perempuan dalam perkawinan sebagai hubungan kekuasaan, dominasi dan kontrol.

"sebagai mutiara, tetapi justru sebagai mana orang menyimpan mutiara di dalam kotak, demikian pulalah mereka menyimpan istrinya itu di dalam kurungan atau pingitan. Bukan untuk memperbudaknya, bukan untuk menghinanya, bukan untuk merendahkannya, katanya, melainkan untuk menghormatinya, untuk memuliakannya.” (Soekarno, 2014:7).

Anggapan tersebut juga memberikan sebuah padangan kepada kita bahwa perlakuan perempuan seperti hal demikian justru membatasi perempuan agar tidak bisa melakukan apa-apa selain mengurus rumah, suami, dan anak-anak saja. Perempuan tidak harus selamanya bekerja dalam ranah domestik. Perempuan juga sepatutnya mendapatkan hak yang sama dengan laki-laki. Cara menghormati perempuan tidak dengan cara bahwa kita mengurung meraka seperti sebuah 
mutiari dalam kotak. Menghormati dan mencintai mereka justru harus dengan sebuah pemahaman agar mereka mendapatkan persamaan hak dengan laki-laki.

Memahami dasar dari suatu permasalahan yang dihadapi oleh perempuan tidak hanya terletak pada ranah domestik saja. Sebuah negara juga ikut bertanggung jawab untuk mengakomodir hak-hak perempuan. Seperti yang di paparkan oleh Gadis Arivia (2006:3) bahwa keterlibatan perempuan disektor publik dan politik harus mencapai 30\%, meskipun presentasi tersebut belum mampu menjamin persamaan hak laki-laki dengan perempuan. Negara juga terkadang lalai menunaikan kewajiban terhadap hak-hak perempuan. Bahkan suatu negara seperti Indonesia masih mengganggap atau mengumpamakan sorang perempuan sebagai seorang Dewi akan tetapi Dewi tersebut justru menjadi Dewi yang tolol.

"Tidaklah masih banyak laki-laki yang mendewi-tolol-kan istrinya itu? Malahan. tidakkah pada hakikatnya seluruh peradaban borjuis di negeri-negeri yang telah "sopan" pada waktu sekarang ini, terhadap kaum perempuan, berdiri atas kenyataan "dewi tolol" itu? Sebab, tidakkah seluruh hukum sipil dan adat istiadat di negeri-negeri borjuis itu sebenarnya masih men-dewi-tololkan perempuan?" (Soekarno, 2014:6).

Kutipan di atas memberikan menggambarkan bahwa negara juga masih menjadi momok bagi kaum perempuan. Negara bersikap arogan dan negara sebagai repsentasi kau borjuis menjadikan perempuan sebagai objek yang paling dirugikan untuk mendapatkan hak-haknya. Dasar masalah telah dipaparkan di atas menunjukkan bahwa perempuan masih mengahadapi perkara domestik (rumah tangga) sebagai penghambat dari sebuah kemerdekaan hak. Selaun itu, negara juga belum bisa memberikan hak yang semestinya kepada para perempuan Indonesia saat itu samapai dengan saat ini.

Suatu gerakan perlawanan perempuan untuk menentang penindasan bisa menjadi hal yang sulit diakibatkan oleh laki-laki yang bertindak tidak adil terhadap perempuan. Ketidakadilan dalam ranah rumah tangga akan menjadi satu kesatuan menjadi ketidakadilan dalam sebuah negara. Hal tersebut bisa kita lihat dalam pembuatan suatu regulasi oleh suatu negara yang mengesampingkan 
kepentingan dan hak perempuan. Kutipan dalam Sarinah sebagai berikut akan menggambarkan ketidakadilan tersebut.

"Masyarakat sekarang di dalam hal ini pun, tidak adil kepada perempuan. Perempuan dalam hal ini pun suatu mahluk yang tertindas. Perempuan bukan saja mahluk yang tertindas kemasyarakatannya, tetapi juga mahluk yang tertindas ke-sekseannya. masyarakat kapitalis zaman sekarang adalah masyarakat, yang membuat pernikahan suatu yang sukar, sering kali suatu hal yang tak mungkin.” (Soekarno, 2014:19)

Kutipan tersebut menggambarkan bahwa masyarakat secara umum tidak adil terhadap perempuan. Selain itu, masyarakat dengan model kapitalis membuat ketertindasan terhadap perempuan semakin kuat. Sistem kapitalis itu justru membawa dampak terhadap perempuan dalam kehiduapan bermasyarakat. Dalam kutipan di atas menggabarkan bahwa akibat masyarakat yang kapitalis menjadikan perempuan kesulitan menikah karena keadaan ekonomi yang juga susah. Sebabsebab itulah yang menjadi dasar perempuan lebih banyak melakukan bunuh diri. Seperti dalam kutipan sebagai berikut.

"Ternyatalah, bahwa di semua negeri ini lebih banyak perempuan muda bunuh diri dari pada laki-laki muda. Sebabnya? Sebabnya tak sukar kita dapatkan. Keseksean yang terhalang, cinta yang tak sampai, kehamilan yang rahasia, itulah biasanya yang menjadi sebab." (Soekarno, 2014:21)

Masyarakat kapitalis selalu menempatkan perempuan sebagai manusia kelas kedua dalam tatanan kehidupan sosial, ekonomi, dan politik. Akibat dari hal tersebut menyebabkan perempuan merasa lemah, terasingkan oleh lingkungan sosial. Sehingga banyak di jumpai perempuan yang cintanya terhalang, hingga terjadi kehamilan di luar nikah, serta jenis kelamanin yang menjadikan sosok mereka lemah. Jadi wajar kemudian banyak di jumpai perempuan yang melakukan hal ekstrim sampai mengahiri hidup atau melakukan bunuh diri.

Pada dasarnya bahwa secara kodrat alam perempuan dan laki-laki tidak meiliki perbedaan. Tetapi, dalam kehidupan masyarakat kita yang memiliki pemahaman partriarki yang kuat justru menempatkan laki-laki mendapatkan hak yang lebih. Selain hak, kedudukan juga menjadi suatu ciri dominasi laki-laki 
terhadap perempuan. Kedudukan-kedudukan tersebut jutru lebih menguntungkan laki-laki dari pada perempuan. Berikut kutipan yang menggambarkan hal-hal tersebut.

"Laki-laki meminta haknya menurut hukum alam, perempuan pun meminta haknya menurut kodrat alam. Ditentang haknya menurut kodrat alam ini tidak ada" perbedaan antara laki-laki dan perempuan. Tapi, masyarakat sekarang, lelaki nyata mendapatkan hak yang lebih, nyata mendapat kedudukan yang lebih, nyata mendapat kedudukan yang lebih menguntungkan." (Soekarno, 2014:23-24)

Bicara gerakan perempuan melawan penindasan di era kapitalis seperti sekarang ini tidaklah mudah. Perempuan sebagai kelas masyarakat yang paling dirugikan dalam kehidupan sosial, politik, terlebih karena ekonomi harus betulbetul paham tentang sebuah perjuangan melawan penindasan terhadap kaumnya. Perjuangan tersebut bisa lebih maksimal dan memiliki hasil yang lebih baik apabila kaum perempuan bisa memahami tentang dasar-dasar dari penindasan terhadap perempuan tersebut.

\section{Kewajiban Perempuan dalam Perjuangan Gerakan Emansipasi}

Kewajiban perempuan dalam perjuangan gerakan emansipasi merupakan suatu keniscayaan bagi kaum perempuan itu sendiri. Keadaan perempuan yang ditindas oleh laki-laki itu pada akhirnya akan membangun atau membangkitkan suatu pergerakan yang berusaha meniadakan penindasan tersebut. Gerakan emansipasi harus berawal dari kaum perempuan sendiri, yakni dengan sebuah kewajiban perempuan memahami suatu konsep serta cara untuk memperjuangkan sebuah gerakan emansipasi. Bagi kaum perempuan memahami konsep dan cara berjuang untuk keluar dari belenggu penindasan adalah dengan mamahami sebuah esensi atau sebuah sejarah dari gerakan perempuan itu sendiri.

"oleh karena di dunia baratlah lahirnya pergerakan wanita mulamula. Di dunia baratlah pertama-tama terdengar semboyan perempuan bersatulah! di dunia baratlah berkembangnya contoh untuk kaum wanita di dunia lain." (Soekarno, 2014:149).

Kutipan tersebut jelas memberikan pencerahan kepada kita bahwa asal muasal suatu gerakan perlawanan oleh perempuan terhadap penindasan. 
Semboyan khusus saat itu menyerukan kepada seluruh perempuan di dunia untuk bersatu memeperjuangan nasibnya supaya tercapai sebuah persamaan atau emansipasi terhadap kaum perempuan. Seruan itu juga di khususkan kepada seluruh perempuan Asia yang belum memiliki kesadaran untuk melawan penindasan tersebut. Selain tetang sebuah penindasan, perempuan juga harus ikut terlibat penuh dalam menuntut hak-haknya sebagai seorang manusia. Seperti pada kutipan berikut ini.

"Baru di dalam revolusi itulah kaum wanita Barat secara tersusun menuntut hak-haknya sebagai manusia, sebagai anggota masyarakat, sebagai warga negara, memprotes kezaliman atas diri mereka sebagai sekse dan sebagai warga negara wanita". (Soekarno, 2014:151)

Kutipan tersebut secara jelas menggambarkan bahwa perempuan harus menuntut persamaan hak dengan laki-laki. Persamaan hak sebagai manusia, sebagai warga negara serta melawan berbagai macam kezaliman laki-laki terhadap perempuan. Selain itu akses perempuan dalam kehidupan sosial politik juga masih dikesampingkan. Maka dengan sendirinya perempuan merasa perlu melawan ketidakadilan tersebut.

Humm (1986:72) mengatakan bahwa perempuan merupakan kelas masyarakat yang tertindas. Sehingga perjuangan perempuan dalam gerakan emansipasi juga merupakan suatu perjuangan kelas, kelas yang dimaksud adalah sebuah perbedaan antara manusia yang satu dengan manusia yang lain. Oleh karena itu, selain memahami sebuah sejarah asal muasal tentang pergerakan perempuan, perempuan harus lebih mendalam memahami tentang esensi dari sebuah perjuangan kelas tersebut.

"Satu gelombang perjuangan kelas, yang tidak kenal perbedaan antara manusia dengan manusia, satu gelombang menuju kepada kemerdekaan, kemerdekaan laki-laki dan kemeredekaan perempuan. Kemerdekaan kelas dan kemerdekaan sekse!" (Soekarno, 2014:162)

Kemerdekaan bagi kaum perempuan tidak hanya tentang batasan memahami sebuah sejarahnya, akan tetapi kemerdekaan bagi perempuan adalah 
sebuah kemerdekaan penuh untuk memperoleh semua akses yang sama dalam kehidupan sosial politk bersama dengan laki-laki. Seperti pada kutipan di atas bahwa perbedaan kelas perempuan dengan laki-laki sangat jelas adanya. Perbedaan kelas itu pula yang menyebabkan laki-laki tidak memberikan ruang kepada perempuan untuk mendapat akses yang sama dengan laki-laki. Bagi kaum laki-laki bahwa perempuan merupakan bagian dari kelas masyarakat rendahan atau kelas masyarakat golongan kedua. Akibat dari itulah perempuan juga memiliki satu gelombang perjuangan yang lebih kompleks untuk melawan penindasan terhadap kaumnya.

Pada perkembangannya pergerakan feminis itu sering juga disebut sebagai pergerakan emansipasi wanita. Gerakan emansipasi ini tidak juga akan mungkin terwujud sepenuhnya dengan hanya perempuan yang terlibat di dalamnya. Peran aktif laki-laki juga perlukan untuk mencapai tujuan kemerdekaan perempuan itu sendiri. Tujuan tersebut akan tercapai apabila perempuan memahami tentang sebuah stratergi serta taktik yang akan digunkan dalam perjuangan tersebut. Senada dengan pemapararan Sofia $(2009,52-59)$ bahwa tindakan yang dilakukan oleh perempuan untuk melepaskan diri dari dominasi patriarki ialah berupaya memberikan pemahaman, berani menolak, dan mengutarakan pendapat, dan mengakhiri hubungan dengan strategi.

"pergerakan sosialisme, dalam mana wanita dan laki-laki bersama-sama berjuang bahu membahu, untuk mendatangkan sosialistis, dalam mana wanita dan laki-laki sama-sama sejahtera, sama-sama merdeka". (Soekarno, 2014:163)

Bisa kita pahami bahwa dalam perjuangan gerakan mencapai emansipasi tersebut perempuan haruslah berjuang bersama-sama denga laki-laki. Laki-laki harus memberikan kemerdekaan secara sepenuhnya kepada kaum perempuan. Memandang perempuan sebagai mahluk yang memiliki persamaan hak dalam lingkungan sosial dan politik pada tatanan kehidupan berbangsa dan bernegara. 
Tabel 1 Hasil dan Pembahasan

\begin{tabular}{|c|c|c|}
\hline No. & Klasifikasi & Nilai Perjuangan Perempuan \\
\hline 1. & $\begin{array}{l}\text { Gerakan Perlawanan } \\
\text { Perempuan untuk } \\
\text { Menentang Penindasan }\end{array}$ & $\begin{array}{l}\text { - "satu soal telah berputar di kepala saya. Bukankah } \\
\text { perempuan yang mengintai tadi itu istrinya tuan } \\
\text { rumah? Mana bisa, tuan rumah toh mengatakan, } \\
\text { bahwa istrinya sedang merawat orang sakit? Tetapi... } \\
\text { mengapa ia tadi kelihatan malu-malu, telinganya } \\
\text { kemerah-merahan, tatkala ditannya di mana } \\
\text { istrinya?" (Soekarno, 2014:4) } \\
\text {-sebagai mutiara, tetapi justru sebagai mana } \\
\text { orang menyimpan mutiara di dalam kotak, } \\
\text { demikian pulalah mereka menyimpan istrinya } \\
\text { itu di dalam kurungan atau pingitan. Bukan } \\
\text { untuk memperbudaknya, bukan untuk } \\
\text { menghinanya, bukan untuk merendahkannya, } \\
\text { katanya, melainkan untuk menghormatinya, } \\
\text { untuk memuliakannya." (Soekarno, 2014:7). } \\
\text { "Tidaklah masih banyak laki-laki yang } \\
\text { mendewi-tolol-kan istrinya itu? Malahan. } \\
\text { tidakkah pada hakikatnya seluruh peradaban } \\
\text { borjuis di negeri-negeri yang telah "sopan" pada } \\
\text { waktu sekarang ini, terhadap kaum perempuan, } \\
\text { berdiri atas kenyataan "dewi tolol" itu? Sebab, } \\
\text { tidakkah seluruh hukum sipil dan adat istiadat di } \\
\text { negeri-negeri borjuis itu sebenarnya masih men- } \\
\text { dewi-tololkan perempuan?" (Soekarno, 2014:6). } \\
\text { "Masyarakat sekarang di dalam hal ini pun, } \\
\text { tidak adil kepada perempuan. Perempuan dalam } \\
\text { hal ini pun suatu mahluk yang tertindas. } \\
\text { Perempuan bukan saja mahluk yang tertindas } \\
\text { kemasyarakatannya, tetapi juga mahluk yang } \\
\text { tertindas ke-sekse-annya. masyarakat kapitalis } \\
\text { zaman sekarang adalah masyarakat, yang } \\
\text { membuat pernikahan suatu yang sukar, sering } \\
\text { kali suatu hal yang tak mungkin." (Soekarno, } \\
\text { 2014:19) } \\
\text { "Ternyatalah, bahwa di semua negeri ini lebih } \\
\text { banyak perempuan muda bunuh diri dari pada } \\
\text { laki-laki muda. Sebabnya? Sebabnya tak sukar } \\
\text { kita dapatkan. Keseksean yang terhalang, cinta } \\
\text { yang tak sampai, kehamilan yang rahasia, itulah } \\
\text { biasanya yang menjadi sebab." (Soekarno, } \\
\text { 2014:21) } \\
\text { "Laki-laki meminta haknya menurut hukum, perempuan pun meminta haknya menurut } \\
\text { kodrat alam. Ditentang haknya menurut kodrat }\end{array}$ \\
\hline
\end{tabular}




\begin{tabular}{|c|c|c|}
\hline & & $\begin{array}{l}\text { alam ini tidak ada" perbedaan antara laki-laki } \\
\text { dan perempuan. Tapi, masyarakat sekarang, } \\
\text { lelaki nyata mendapatkan hak yang lebih, nyata } \\
\text { mendapat kedudukan yang lebih, nyata } \\
\text { mendapat kedudukan yang lebih } \\
\text { menguntungkan." (Soekarno, 2014:23-24) }\end{array}$ \\
\hline 2. & $\begin{array}{l}\text { Kewajiban Perempuan } \\
\text { dalam Perjuangan } \\
\text { Gerakan Emansipasi }\end{array}$ & $\begin{array}{l}\text { - "oleh karena di dunia baratlah lahirnya } \\
\text { pergerakan wanita mula-mula. Di dunia baratlah } \\
\text { pertama-tama terdengar semboyan perempuan } \\
\text { bersatulah! di dunia baratlah berkembangnya } \\
\text { contoh untuk kaum wanita di dunia lain." } \\
\text { (Soekarno, 2014:149). } \\
\text { "Baru di dalam revolusi itulah kaum wanita } \\
\text { Barat secara tersusun menuntut hak-haknya } \\
\text { sebagai manusia, sebagai anggota masyarakat, } \\
\text { sebagai warga negara, memprotes kezaliman } \\
\text { atas diri mereka sebagai sekse dan sebagai } \\
\text { warga negara wanita". (Soekarno, 2014:151) } \\
\text { "Satu gelombang perjuangan kelas, yang tidak } \\
\text { kenal perbedaan antara manusia dengan } \\
\text { manusia, satu gelombang menuju kepada } \\
\text { kemerdekaan, kemerdekaan laki-laki dan } \\
\text { kemeredekaan perempuan. Kemerdekaan kelas } \\
\text { dan kemerdekaan sekse!" (Soekarno, 2014:162) } \\
\text { "pergerakan sosialisme, dalam mana wanita dan } \\
\text { laki-laki bersama-sama berjuang bahu } \\
\text { membahu, untuk mendatangkan sosialistis, } \\
\text { dalam mana wanita dan laki-laki sama-sama } \\
\text { sejahtera, sama-sama merdeka". (Soekarno, } \\
\text { 2014:163) }\end{array}$ \\
\hline
\end{tabular}

\section{KESIMPULAN}

Berdasarkan uraian pembahasan di atas dapat disimpulkan bahwa perjuangan perempuan untuk menentang penindasan serta mendapatkan persamaan hak dengan laki-laki sudah terjadi sejak dulu. Perjuangan tersebut sudah tertuang dalam pemaparan Soekarno dengan karyanya yang berjudul Sarinah. Bentuk dari gerakan perlawanan oleh perempuan ditandai dengan kemampuan perempuan untuk memahami tentang asal muasal penindasan terhadap kaumnya. Sehingga dalam perkembangannya perempuan dapat menuntut persamaan hak sepenuhnya dengan laki-laki, baik itu hak secara sosial masyarakat hinggga hak secara politis. Selain itu juga perempuan memahami arti penting 
sebuah emansipasi untuk kaum perempuan. Guna mencapai tujuan dari gerakan tersebut perempuan harus bekerja sama dengan laki-laki serta bahu membahu untuk memperjuangan hak-haknya secara penuh. Pada akhirnya tidak ada lagi perbedaan kelas dalam kehidpan berbangsa dan bernegara.

\section{SARAN}

Penelitian ini dapat dijadikan sebagai salah satu sumber semangat perjuangan perempuan untuk mendapatkan persamaan hak dengan laki-laki, hak dalam kehidupan sosial, ekonomi, dan politik. Hasil penelitian ini juga dapat dijadikan sebagai referensi untuk pembelajaran sastra di dalam lingkungan pendidikan serta menjadi acuan untuk penelitian-penelitian selanjutnya.

\section{DAFTAR PUSTAKA}

Aminullah, Ilhamuddin. 2012. Perjuangan Tokoh-Tokoh Perempuan dalam Novel Dwilogi Padang Bulan Karya Andrea Hirata dan Relevansinya dengan Pembelajaran Sastra. Tesis Universitas Mataram, Mataram.

Arivia, Gadis. 2006. Feminis: Sebuah Kata Hati. Jakarta: Memoar Kompas.

Beauvoir, Simone de. 2003. Second Sex: Fakta dan Mitos. Surabaya: Pustaka Promothea.

Darma, Yoce Aliah. 2009. Analisis Wacana Kritis. Bandung: Yrama Widia.

Fakih, Mansour. 2010. Analisis Gender dan Transformasi Sosial. Yogyakarta: Pustaka Pelajar.

Humm, Maggie. 1986. Feminist Criticism. Great Britain: The Harvester Press.

Madsen, Deborah L. 2000. Feminist Theory and Literary Praktice. London: Pluto Press.

Moleong, Lexy, 2002. Metodologi Penelitian Kualitatif. Bandung. PT. Remaja Rosdakarya.

Priyatni, Endah Try. 2010. Membaca Sastra dengan Ancangan Literasi Kritis. Jakarta: Bumi Aksara.

Rama and Jones. 2011. Sistem Informasi Akutansi I. Jakarta: Salemba Empat. 
Ratna, Nyoman Kutha. 2010. Sastra dan Culture Studies Representasi Fiksi dan Fakta. Yogyakarta: Pustaka Pelajar.

Ratna, Nyoman Kutha. 2011. Teori, Metode, dan Teknik Penelitian Sastra. Yogyakarta: Pustaka Pelajar.

Soekanto, Soerjono. 2009. Sosiologi Suatu Pengantar. Jakarta: Rajawali Pers.

Soekarno. 2014. Sarinnah: Kewajiban Wanita Dalam Perjuangan Republik Indonesia. Yogyakarta: Media Persindo dan Yayasan Bung Karno.

Sofia, Adib. 2009. Kritik Sastra Feminis: Perempuan Dalam Karya-karya Kuntowijoyo. Yogyakarta: Citra Pustaka.

Sugishastuti. 2009. Rona Bahasa dan Sastra Indonesia: Tanggapan Penutur dan Pembacanya. Yogyakarta: Pustaka Pelajar.

Zuhairini, Siti. 2013. Idealisme Perjuangan Perempuan Sasak Dalam Novel Merpati Kembar di Lombok Karya Nuriadi dan Relevansinya Terhadap Pembelajaran Sastra di SMAN 2 Kediri Lombok Barat. Tesis Universitas Mataram, Mataram. 